\title{
1 - Editorial
}

Nesta nova fase da Revista, neste editorial, gostaríamos apenas de apresentar ao leitor de hoje e ao colaborador de amanhã a nossa linha editorial, que será pautada por seis diretrizes principais.

A primeira é o pluralismo de idéias, experiências, doutrinas, opiniões, teorias, jurisprudências e argumentaçōes. Acreditamos que um necessário pluralismo decorre de uma tripla exigência. Por um lado, é inerente à própria prática profissional jurídica, onde o contraditório é o caminho privilegiado do devido processo legal e da busca do justo. Faz parte da cultura jurídica o confronto de idéias. Por outro, epistemologicamente, o pluralismo é exigência do próprio processo do avanço do conhecimento em seus múltiplos graus de cientificidade. Aceitar, discordar e refutar, o acordo e o desacordo, a comprovação da veracidade e a constatação da falsidade, a dialética, a competição entre os diferentes - paradoxalmente, essas formas de oposição entre opiniōes somam e fazem avançar a civilização contemporânea. Finalmente, o pluralismo de idéias decorre também da múltipla natureza da sociedade brasileira, feita de interesses sociais, econômicos, culturais e religiosos os mais diversificados possíveis. Uma multiplicidade que invariavelmente se traduz, com maior ou menor ênfase, em doutrinas, pareceres, projetos de lei, dispositivos constitucionais e decisōes judiciais.

A segunda diretriz é o estímulo à inovação, a originalidade do pensamento jurídico, sobretudo aquele que se fundamenta na realidade do direito brasileiro. Entendemos que uma das responsabilidades principais da RDA, sobretudo neste período de globalização, em que o mercado internacional de idéias se torna mais vigoroso e expansionista, é estimular o Brasil a participar mais e mais deste mercado. Menos pela importação de idéias e exemplos dos países matrizes, do mimetismo do século XIX, embora com ele sempre dialogando, e mais na análise e na reconstrução do direito e das práticas profissionais a partir da experiência brasileira autóctone. A partir de um saber de experiência feito. O universal não é o igual, já antes foi dito. Ou, como diria Tolstoi, para ser universal, escreva sobre sua aldeia.

E terceira diretriz contempla uma realidade cada dia mais evidente: o crescente envolvimento entre o direito, a economia, a cultura e a política. Houve época, já passada, onde um exacerbado formalismo dogmático pretendeu afastar do conhecimento sobre direito - $\mathrm{e}$, portanto, do âmbito do profissional jurídico - as questōes valorativas e que envolvessem o conteúdo das leis. Hoje, não mais. É quase impossível pensar o Estado brasileiro ou mesmo a decisāo judicial sem avaliar as conseqüências econômicas, sociais e políticas da decisão jurídica. Não se pode propor uma inovação na legislação processual sem que se analise qual o seu impacto nos custos para o Poder Judiciário e para as partes litigantes, e em quanto uma 
nova lei acelera ou retarda a obtenção da sentença definitiva. Dificilmente vamos entender o papel das agências reguladoras e sua normatividade sem entender os interesses dos agentes e os mecanismos de funcionamento do mercado. Estimular a produção de artigos e trabaIhos que colaborem para a criação de uma cultura, seja inter ou transdisciplinar, e sobretudo jurídico-econômica, dos institutos e processos jurídicos é uma de nossas diretrizes principais. Mesmo porque, nesta área, a prática profissional, tanto do Poder Executivo, quanto das empresas, já está bem mais avançada do que a reflexão acadêmica.

A quarta diretriz é abrir a RDA aos novos campos do saber jurídico, que já se delineiam como indispensáveis ao profissional de direito e favoritos na reflexão acadêmica neste começo de século XXI. Abrir decisivamente para as relaçôes entre direito e tecnologia, para a Internet, e a conseqüente reformulação do direito de propriedade intelectual. Saber lidar e regular o real que é virtual. Abrir para as relaçōes entre direito e biotecnologia e os intrincados problemas morais que levantam. Abrir para os problemas ambientais, cada dia mais relevantes para o direito interno e para o direito global, e para a própria reconstrução desse direito internacional em direito global. Trata-se, enfim, de promover um debate o mais permeável possível para os novos saberes indispensáveis à criação e ao aperfeiçoamento de instituiçōes jurídicas nacionais.

A quinta diretriz é o compromisso da RDA com o fortalecimento da democracia, isto é, com a consolidação do Estado Democrático.

Este é o cerne da natureza do Estado Brasileiro. O século XX foi o século da democracia. Em 1900, tínhamos pouco mais de 20 estados independentes que poderíamos denominar democráticos. No final no ano 2000 , eram mais de 120 . O século XXI será o século no qual estas democracias vão ser postas à prova e assumirão formas diferenciadas em busca do mesmo fim: a inevitável convivência dos cidadãos, que se quer pacífica. com a indispensável liberdade de cada um. Aliás, as democracias já estão sendo postas à prova com a tendência já observável ao redor do mundo de expansão das prerrogativas do Estado e da conseqüente diminuição dos espaços de liberdade, privacidade e autonomia dos cidadãos diante de epidemias, terrorismo, imigração, dano ambiental, pobreza e tantas outras questōes contemporâneas.

Finalmente, a sexta e última diretriz decorre do compromisso com o Estado de Direito. A RDA se compromete com o aprimoramento do Poder Judiciário, por entender que não haverá democracia forte no Brasil sem um Poder Judiciário ágil, politicamente legítimo, com garantia de pleno acesso a todos os brasileiros, socialmente igualitário: economicamente eficiente e preparado para o combate à corrupção e para zelar pela manutenção da retidão e da honestidade na conduta dos negócios públicos, pois, como afirmado por Cícero, "fazem muito mal à República os políticos corruptos, pois não apenas se impregnam de vícios eles mesmos, mas os infundem na sociedade, e não apenas a prejudicam por se corromperem, mas também porque a corrompem, e são mais nocivos pelo exemplo do que pelo crime".

Este é um tema prioritário, pois passa pela integração do país na paz. Estudos e pesquisas - inclusive estatísticas - que nos ajudem a mapear e mais bem conhecer a realidade judicial serāo muito bem-vindos.

A RDA, por isto, não se limita às questões administrativas que digam respeito apenas ao Poder Executivo. Temos sempre um espaço para as questōes administrativas do Poder Judiciário, de importância ainda maior com a recente criação do Conselho Nacional de Justiça. Da mesma maneira, temos espaços para as questōes administrativas referentes ao Poder Legislativo em suas múltiplas esferas, inclusive no tocante à valorização na atuação dos Tribunais de Contas. 